\title{
Celiac crisis in an adult on immunosuppressive therapy
}

\author{
Owayed Al Shammeri MBBS, Donald R Duerksen MD FRCPC
}

O Al Shammeri, DR Duerksen. Celiac crisis in an adult on immunosuppressive therapy. Can J Gastroenterol 2008;22(6): 574-576.

\begin{abstract}
'Celiac crisis' is a rare presentation of celiac disease with manifestations that include severe diarrhea, and severe metabolic and electrolyte abnormalities. It is most frequently seen in children younger than two years of age and has been rarely described in adults. A case of a 50-year-old woman who presented with diarrhea, severe dehydration, hypokalemia and metabolic acidosis is described. Based on positive serology and small bowel biopsy, she was diagnosed with celiac disease. She also had histological evidence of lymphocytic colitis. Microscopic colitis has not previously been described in association with celiac crisis, but it may have contributed to the presentation of celiac crisis in the current case. The patient was on corticosteroids and azathioprine for autoimmune hepatitis at the time of her presentation. The current case demonstrates that modest immunosuppression does not prevent a celiac crisis, although previous reports have shown that patients may respond rapidly to high-dose corticosteroids.
\end{abstract}

\section{Une crise cœliaque chez un adulte prenant des immunosuppresseurs}

\begin{abstract}
La crise cœliaque est une présentation rare de maladie cœliaque dont les manifestations incluent la diarrhée abondante et de graves anomalies métaboliques et électrolytiques. On l'observe surtout chez des enfants de moins de deux ans. Elle est rarement décrite chez les adultes. Est présenté le cas d'une femme de 50 ans qui a consulté à cause d'une diarrhée, d'une déshydratation marquée, d'une hypokaliémie et d'une acidose métabolique. D'après une sérologie positive et une biopsie de l'intestin grêle, on a diagnostiqué une maladie cœliaque. La femme présentait également des manifestations histologiques de colite lymphocytaire. On n'a jamais décrit de colite microscopique en association avec la crise cœliaque, mais dans le présent cas, elle peut avoir contribué à la présentation de la crise coliaque. La patiente prenait des corticoïdes et de l'azathioprine pour soigner une hépatite auto-immune au moment de la consultation. Le présent cas démontre qu'une modeste immunosuppression ne prévient pas une crise cœliaque, même si des articles précédents ont démontré que les patients peuvent répondre rapidement à de fortes doses de corticoïdes.
\end{abstract}

Key Words: Acidosis; Celiac crisis; Celiac disease

W ith the advent of serological testing for celiac disease, it has become evident that the presentation of celiac disease can vary. The spectrum of presentation includes asymptomatic individuals with a family history of iron deficiency, individuals with symptoms of mild bloating and diarrhea, and patients with significant weight loss and malabsorption (1). One rare presentation of celiac disease is the so-called 'celiac crisis' (2). This syndrome includes the rapid onset of lifethreatening acidosis, hypokalemia and dehydration in association with severe diarrhea, and has been more frequently described in pediatric patients younger than two years of age $(3,4)$. The present study describes a case of a 50-year-old woman on immunosuppressive therapy for autoimmune hepatitis who presented with 'celiac crisis'. The patient also had evidence of associated microscopic colitis on colonoscopy. The occurrence of celiac crisis in adults, and the effects that immunosuppressive therapy and the coexistence of microscopic colitis may have had on the patient are reviewed.

\section{CASE PRESENTATION}

A 50-year-old woman presented to the hospital with ascites. Her computed tomography scan results were suggestive of cirrhosis. Based on a workup that included a positive smooth muscle antibody result, increased immunoglobulin (Ig) G level (22 g/L; normal level between $6.43 \mathrm{~g} / \mathrm{L}$ and $13.92 \mathrm{~g} / \mathrm{L})$ and a liver biopsy that demonstrated chronic active hepatitis, she was diagnosed with autoimmune chronic hepatitis. She was started on prednisone $30 \mathrm{mg} /$ day and azathioprine $100 \mathrm{mg} /$ day. Over the next two months, her liver enzymes began to gradually improve. She was continued on the above immunosuppressive regimen because of the gradual enzyme improvement.

Her medical history was significant for hypothyroidism, and she was put on thryoid replacement therapy. There was no significant family history of gastrointestinal disorders. She was taking spironolactone $200 \mathrm{mg} /$ day, which controlled her ascites. She reported no recent travel history.

She had a one- to two-year history of passing four to five loose stools per day. However, in the two weeks before hospital admission, she had developed severe watery diarrhea with more than 10 bowel movements per day and nocturnal bowel movements. She did not have significant abdominal pain and had noted no blood in her stools. She was admitted to the hospital with increasing weakness, and her blood test showed the following: sodium $127 \mathrm{mmol} / \mathrm{L}$; potassium $2.6 \mathrm{mmol} / \mathrm{L}$; chloride $101 \mathrm{mmol} / \mathrm{L}$; total $\mathrm{CO}_{2} 12 \mathrm{mmol} / \mathrm{L}$; urea $17.4 \mathrm{mmol} / \mathrm{L}$ and creatinine $187 \mu \mathrm{mol} / \mathrm{L}$. She was initially treated with intravenous (IV) normal saline and bicarbonate. Her weight at the time of admission was $85.7 \mathrm{~kg}$ and after rehydration, her weight improved to $89.1 \mathrm{~kg}$. Her dehydration was corrected by normalization of her urea and creatinine levels. Her diarrhea

Department of Medicine, University of Manitoba, Winnipeg, Manitoba

Correspondence: Dr Donald R Duerksen, Division of Gastroenterology, C5120 409 Taché Avenue, St Boniface Hospital, Winnipeg, Manitoba

R2H 2A6. Telephone 204-237-2796, fax 204-233-7154, e-mail duerksn@cc.umanitoba.ca

Received for publication November 13, 2007. Accepted February 5, 2008 
continued in the hospital. An arterial blood gas performed several days after admission revealed the following: $\mathrm{pH}$ 7.16; $\mathrm{O}_{2}$ partial pressure $106 \mathrm{mmHg} ; \mathrm{CO}_{2}$ partial pressure $14 \mathrm{mmHg}$ and bicarbonate $5 \mathrm{mmol} / \mathrm{L}$. There was no evidence of renal tubular acidosis and her non-anion gap metabolic acidosis was attributed to her diarrhea.

Investigations for diarrhea included an elevated stool osmotic gap $(94 \mathrm{mOsm} / \mathrm{kg})$ and negative stool cultures for bacterial pathogens, ova, parasites and Clostridium difficile. A colonoscopy demonstrated normal colonic mucosa, and random biopsies demonstrated changes consistent with lymphocytic colitis and increased intraepithelial lymphocytes. Her IgA endomysial antibody test result was positive (1:160 dilution), as was her IgA tissue transglutaminase antibody test result (15 EU/mL; normal less than $10 \mathrm{EU} / \mathrm{mL})$. A subsequent small bowel biopsy confirmed celiac disease with villous atrophy, crypt hypertrophy and increased inflammatory infiltrate. Her immunosuppressive therapy of azathioprine $(100 \mathrm{mg} /$ day $)$ and prednisone $(30 \mathrm{mg} /$ day $)$ was continued in the hospital. Her liver enzymes remained stable. She was treated with a gluten-free diet, and over the ensuing three weeks, she made a substantial improvement with resolution of her diarrhea; normalization of electrolyte, urea and creatinine levels; and resolution of her acidosis. She has remained well on a gluten-free diet, with no recurrence of diarrhea. She has been maintained on azathioprine $200 \mathrm{mg} /$ day for autoimmune hepatitis. A repeat colonoscopy one year after her discharge demonstrated resolution of the histological findings of microscopic colitis.

\section{DISCUSSION}

There are several unique aspects to this case with respect to celiac disease and its presentation. First, the presentation of celiac disease with severe acidosis, dehydration and hypokalemia has been rarely described in adult patients. In recent years, celiac disease has been shown to present in many diverse ways, commonly with mild gastrointestinal symptoms and no major electrolyte abnormalities (5). Celiac crisis was first described in pediatric patients in 1952 when Andersen and di Sant'agnese $(3,4)$ described the course of celiac disease in 58 children. In 35 of these patients, the symptoms at presentation were sudden dehydration and acidosis, and this was only seen in patients younger than two years of age. In 2000, Wolf et al (2) reported an adult who presented with severe acidosis and hypokalemia and who responded to a gluten-free diet. Since then, two other reports $(6,7)$ have described three adults who presented with severe diarrhea, acidosis and hypokalemia, and who were subsequently diagnosed with celiac disease. Table 1 summarizes the presentation and abnormalities seen in these patients. All of these patients' symptoms and metabolic derangements resolved with a gluten-free diet.

The cause of 'celiac crisis' is unclear. In the reported adult cases, the patients presented with relatively acute onset watery diarrhea, although chronic symptoms have also been present in some cases (6). This is similar to our case, in which the patient had chronic mild diarrhea for one to two years before developing severe watery diarrhea several weeks before hospital admission. There have been no documented infections that may have precipitated this condition. In our case, examinations were negative for bacterial pathogens, $\mathrm{C}$ difficile infections and parasites. The present report is the first to demonstrate microscopic colitis in association with a celiac
TABLE 1

Characteristics of reported cases of 'celiac crisis'

\begin{tabular}{|c|c|c|c|c|c|}
\hline & \multicolumn{5}{|c|}{ Case (reference) } \\
\hline & $1(2)$ & $2(6)$ & $3(6)$ & $4(7)$ & $5^{*}$ \\
\hline Age, years & 36 & 75 & 55 & 30 & 50 \\
\hline Sex & Female & Male & Female & Female & Female \\
\hline $\begin{array}{l}\text { Potassium, } \\
\mathrm{mmol} / \mathrm{L}\end{array}$ & 2.80 & 2.30 & 2.60 & 2.10 & 1.60 \\
\hline $\begin{array}{l}\text { Total } \mathrm{CO}_{2} / \mathrm{HCO}_{3} \\
\text { mmol/L }\end{array}$ & 12.00 & 14.00 & 17.00 & - & 5.00 \\
\hline $\mathrm{pH}$ & 7.21 & 7.15 & 7.22 & - & 7.16 \\
\hline Urea, mmol/L & 2.50 & 21.20 & 9.00 & - & 17.40 \\
\hline Creatinine, $\mu \mathrm{mol} / \mathrm{L}$ & - & 230.00 & 90.00 & - & 187.00 \\
\hline Diarrhea $^{\dagger}$, days & 9 & 7 & 3 & 30 & 14 \\
\hline
\end{tabular}

${ }^{*}$ Current case; ${ }^{\dagger}$ Duration of watery diarrhea before hospital presentation. $\mathrm{HCO}_{3}$ Bicarbonate

crisis. The association between microscopic colitis and celiac disease has been described (8); microscopic colitis may be one of the causes of failure to respond to a gluten-free diet $(9,10)$. None of the other reported cases of celiac crisis in adults looked for microscopic colitis. Microscopic colitis by itself does not result in metabolic acidosis, and has not been reported to cause severe dehydration and hypokalemia in association with celiac disease. We hypothesize that it may be one factor that contributes to the development of this rare presentation. Microscopic colitis has been associated with defective active and passive absorption of sodium and chloride, and reduced chloride-bicarbonate exchange (11), although the latter seems to be more associated with collagenous colitis.

Finally, the present report is the first to describe an adult patient with celiac crisis who was receiving immunosuppressive therapy at the time of presentation. Immunosuppressive therapy may be used to treat patients with refractory celiac disease (RCD), a rare condition of nonresponse to a strict glutenfree diet (12). Initial reports described the response of celiac disease to corticosteroids (13) and, because of frequent relapse once corticosteroids are stopped, subsequent small series have reported the maintenance of remission with azathioprine $(14,15)$. More recent case reports and small series have reported the response of RCD to cyclosporine and budesonide. In a series of 13 patients with RCD, eight responded clinically and histologically to oral cyslosporine (16). Budesonide has also been effective, with $76 \%$ of 29 patients responding clinically in one series (with no histological response) (17) and seven of nine patients responding in another series (18). Patients with RCD type 1 (normal intraepithelial lymphocytes) appear to respond better to immunosuppressive therapy than those with RCD type 2 (phenotypically immature intraepithelial lymphocytes) (14). Cytokine modulators have also been used to treat RCD. Several case reports (19-21) have shown the clinical and histological benefits of antitumour necrosis factor-alpha therapy. Interleukin-10 has an inhibitory effect on $\mathrm{T}$ lymphocytes, but a nonrandomized open-label study (22) in 10 patients with RCD showed little benefit associated with this therapy.

Immunosuppressive therapy decreases the inflammatory response in celiac disease (13), and we hypothesize that the 
likelihood of someone developing a 'celiac crisis' would be less in patients on immunosuppressive therapy. Although immunosuppressive therapy may be used to treat RCD, symptomatic celiac disease may develop in patients on immunosuppressive therapy (23). The present case demonstrates that immunosuppressive therapy is not sufficient to prevent the presentation of a celiac crisis. Immunosuppressive therapy was effective in treating a celiac crisis in four pediatric patients $(24,25)$. The doses used were prednisone $1.5 \mathrm{mg} / \mathrm{kg} /$ day, IV hydrocortisone $10 \mathrm{mg} / \mathrm{kg} /$ day and IV hydrocortisone $20 \mathrm{mg} / \mathrm{kg} /$ day. The doses used in these reports are substantially higher than what our patient was receiving. Lloyd-Still et al (24) reported a dramatic response to corticosteroids, with significant improvement $24 \mathrm{~h}$ after infusion of corticosteroids. Our patient responded gradually to a glutenfree diet (over approximately three weeks) and this gradual

\section{REFERENCES}

1. Fasano A. Celiac disease - how to handle a clinical chameleon. N Engl J Med 2003;348:2568-70.

2. Wolf I, Mouallem M, Farfel Z. Adult celiac disease presented with celiac crisis: Severe diarrhea, hypokalemia, and acidosis. J Clin Gastroenterol 2000;30:324-26.

3. Andersen DH, di Sant'Agnese PA. Idiopathic celiac disease. I. Mode of onset and diagnosis. Pediatrics 1953;11:207-23.

4. di Sant'Agnese PA. Idiopathic celiac disease. II. Course and prognosis. Pediatrics 1953;11:224-37.

5. Rostom A, Murray JA, Kagnoff MF. American Gastroenterological Association (AGA) Institute technical review on the diagnosis and management of celiac disease. Gastroenterology 2006;131:1981-2002.

6. Ozaslan E, Koseoglu T, Kayhan B. Coeliac crisis in adults: Report of two cases. Eur J Emerg Med 2004;11:363-5.

7. Gupta T, Mandot A, Desai D, Abraham P, Joshi A. Celiac crisis with hypokalemic paralysis in a young lady. Indian J Gastroenterol 2006;25:259-60.

8. DuBois RN, Lazenby AJ, Yardley JH, Hendrix TR, Bayless TM, Giardiello FM. Lymphocytic enterocolitis in patients with 'refractory sprue'. JAMA 1989;262:935-7.

9. Fine KD, Meyer RL, Lee EL. The prevalence and causes of chronic diarrhea in patients with celiac sprue treated with a gluten-free diet. Gastroenterology 1997;112:1830-8. (Erratum in 1998;114:424-5)

10. Leffler DA, Dennis M, Hyett B, Kelly E, Schuppan D, Kelly CP. Etiologies and predictors of diagnosis in nonresponsive celiac disease. Clin Gastroenterol Hepatol 2007;5:445-50.

11. Protic M, Jojic N, Bojic D, et al. Mechanism of diarrhea in microscopic colitis. World J Gastroenterol 2005;11:5535-9.

12. O'Mahony S, Howdle PD, Losowsky MS. Review article: Management of patients with non-responsive coeliac disease. Aliment Pharmacol Ther 1996;10:671-80.

13. Hamilton JD, Chambers RA, Wynn-Williams A. Role of gluten, prednisone, and azathioprine in non-responsive coeliac disease. Lancet 1976;1:1213-6. response may have been partly due to the fact that the corticosteroid dose was not increased.

\section{CONCLUSIONS}

Celiac crisis is an uncommon presentation in adults. This diagnosis should be considered when patients present with unexplained severe diarrhea, metabolic acidosis, hypokalemia and dehydration. Microscopic colitis may be one of the factors that contribute to the development of this condition. Although modest immunosuppression does not prevent a celiac crisis, previous reports have shown that patients may respond to high-dose corticosteroids.

DISCLOSURE: The authors report no conflicts of interest.
14. Goerres MS, Meijer JW, Wahab PJ, et al. Azathioprine and prednisone combination therapy in refractory coeliac disease. Aliment Pharmacol Ther 2003;18:487-94.

15. Maurino E, Niveloni S, Chernavsky A, et al. Azathioprine in refractory sprue: Results from a prospective, open-label study. Am J Gastroenterol 2002;97:2595-602.

16. Wahab PJ, Crusius JB, Meijer JW, Uil JJ, Mulder CJ. Cyclosporin in the treatment of adults with refractory coeliac disease - an open pilot study. Aliment Pharmacol Ther 2000;14:767-74.

17. Brar P, Lee S, Lewis S, Egbuna I, Bhagat G, Green PH. Budesonide in the treatment of refractory celiac disease. Am J Gastroenterol 2007;102:2265-9.

18. Daum S, Ipczynski R, Heine B, Schulzke JD, Zeitz M, Ullrich R. Therapy with budesonide in patients with refractory sprue. Digestion 2006;73:60-8.

19. Gaia S, Bruno M, Marzano A, et al. A case of ulcerative jejunoileitis treated with anti tumor necrosis factor-alpha antibodies. Panminerva Med 2005;47:269-72.

20. Turner SM, Moorghen M, Probert CS. Refractory coeliac disease: Remission with infliximab and immunomodulators. Eur J Gastroenterol Hepatol 2005;17:667-9.

21. Gillett HR, Arnott ID, McIntyre M, et al. Successful infliximab treatment for steroid-refractory celiac disease: A case report. Gastroenterology 2002;122:800-5.

22. Mulder CJ, Wahab PJ, Meijer JW, Metselaar E. A pilot study of recombinant human interleukin-10 in adults with refractory coeliac disease. Eur J Gastroenterol Hepatol 2001;13:1183-8.

23. Duerksen DR, Ma MM, Jewell LD. Failure of immunosuppressive therapy to prevent relapse of celiac sprue. J Clin Gastroenterol 1995;21:255-7.

24. Lloyd-Still JD, Grand RJ, Khaw KT, Shwachman H. The use of corticosteroids in celiac crisis. J Pediatr 1972;81:1074-81.

25. Baranwal AK, Singhi SC, Thapa BR, Kakkar N. Celiac crisis. Indian J Pediatr 2003;70:433-5. 


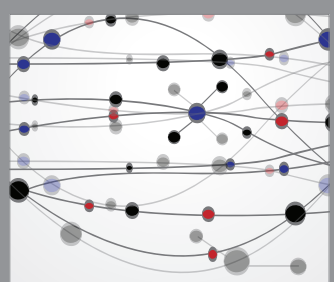

The Scientific World Journal
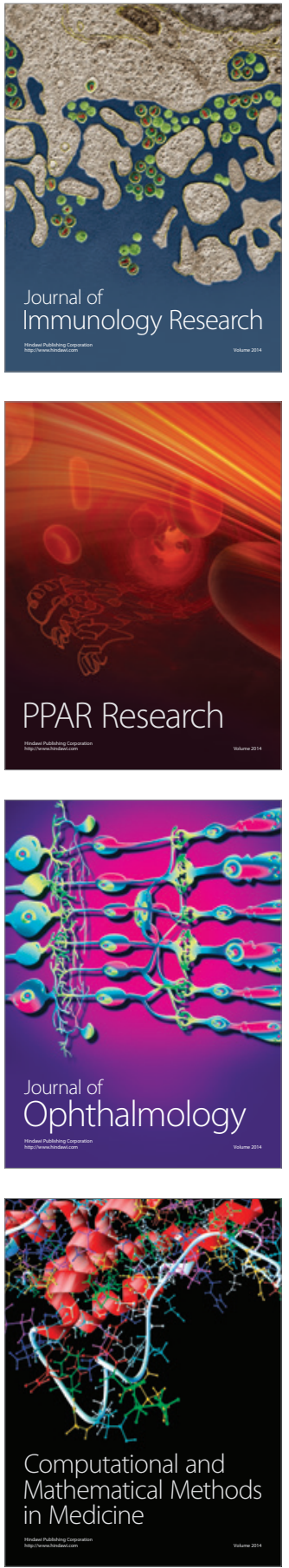

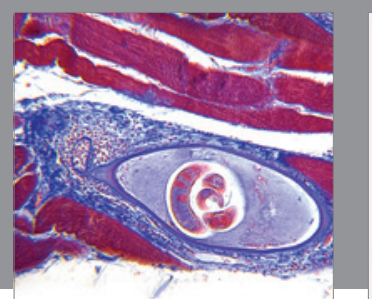

Gastroenterology Research and Practice

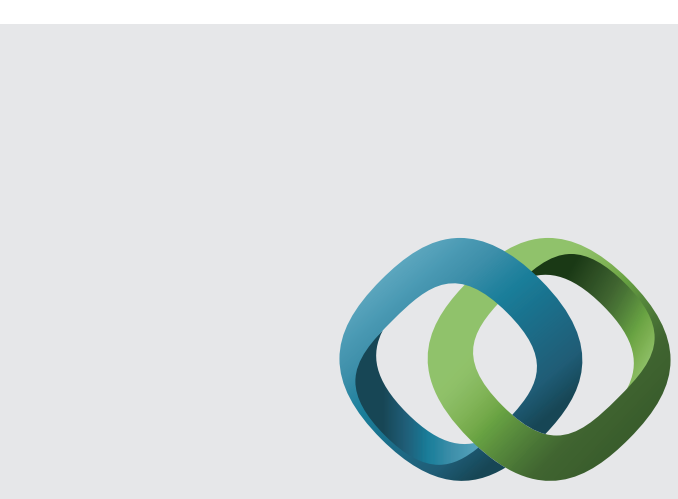

\section{Hindawi}

Submit your manuscripts at

http://www.hindawi.com
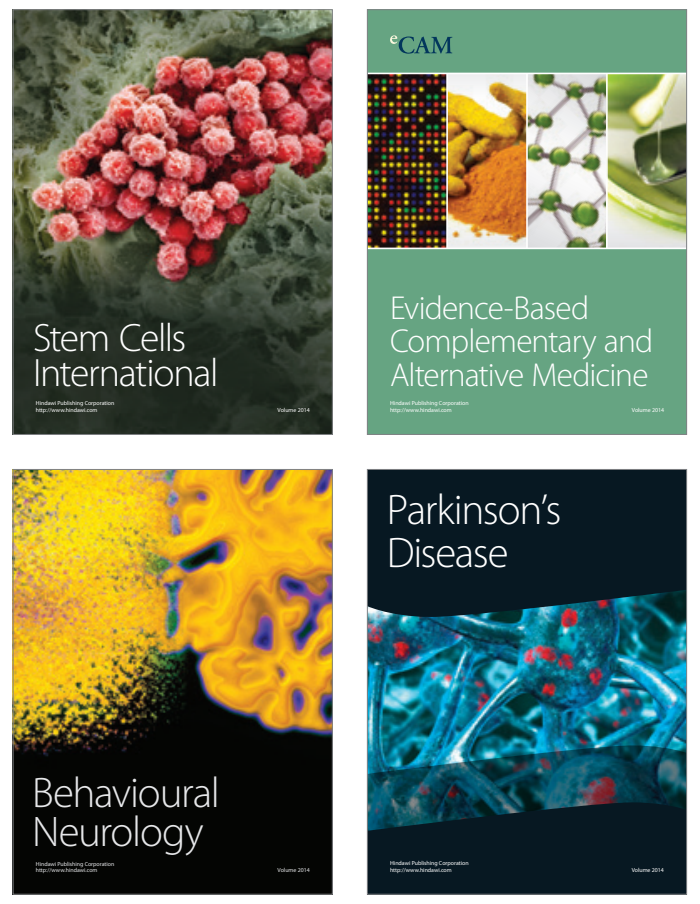
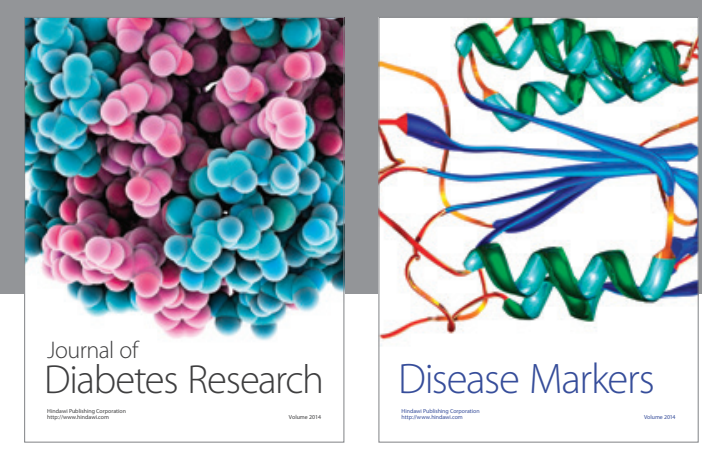

Disease Markers
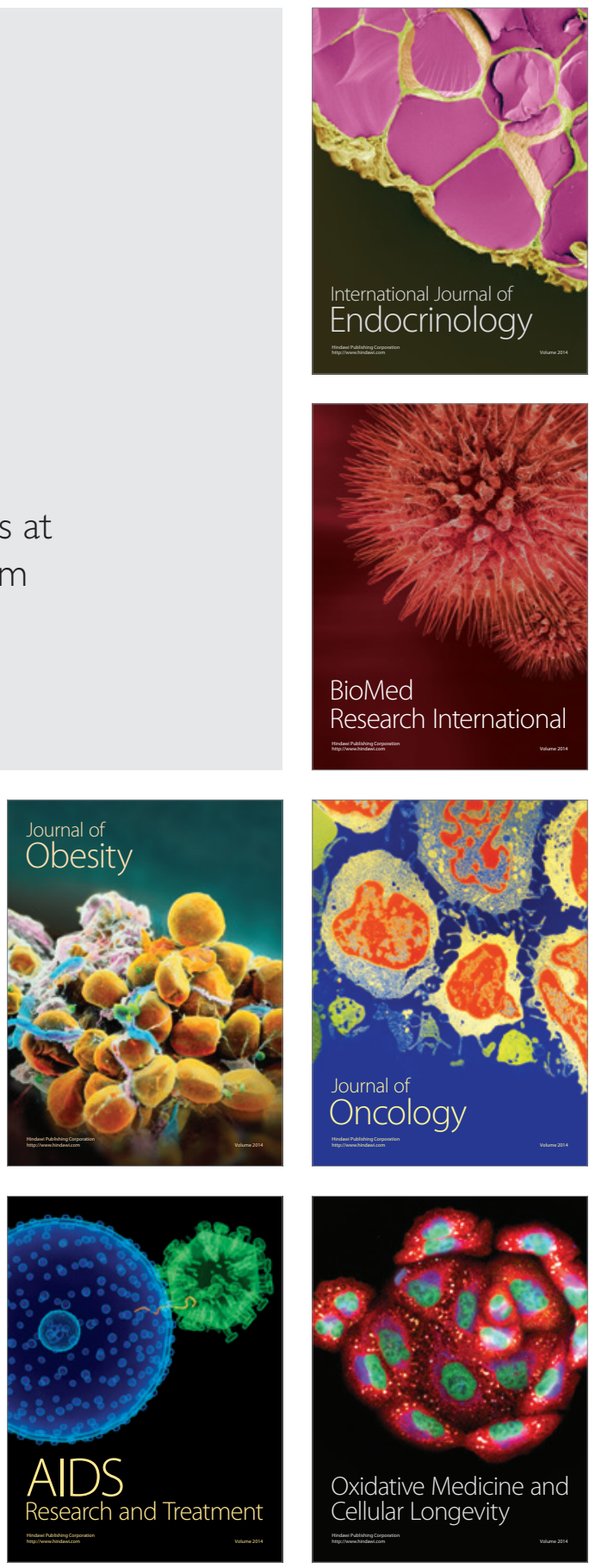